\title{
Seasonal variation in dimethylsulfoniopropionate related to microphytobenthos composition in intertidal estuarine sediments
}

\author{
S. A. van Bergeijk ${ }^{1,3}$, U. Wollenzien ${ }^{2}$, K. Schönefeldtt ${ }^{1}$ L. J. Stal ${ }^{2, *}$ \\ ${ }^{1}$ Aquatic Microbiology, Institute for Biodiversity and Ecosystem Dynamics, University of Amsterdam, \\ Nieuwe Achtergracht 127, 1018 WS Amsterdam, The Netherlands \\ ${ }^{2}$ Department of Marine Microbiology, Netherlands Institute of Ecology - KNAW, PO Box 140, 4400 AC Yerseke, The Netherlands \\ ${ }^{3}$ Present address: Departamento de Biología, Facultad de Ciencias del Mar, Universidad de Cádiz, Campus Rio San Pedro s/n, \\ 11510 Puerto Real, Spain
}

\begin{abstract}
Dimethylsulfoniopropionate (DMSP) and algal pigments were measured monthly over 1 yr (May 1997 to June 1998) in intertidal sediments at 2 sampling sites along the Wester- and Oosterschelde (Netherlands). Temperature, salinity and dissolved inorganic nitrogen (DIN) were measured in the pore water and qualitative microscopic observations were made on the microphytobenthos present in the sediment. Both DMSP and pigment content correlated positively with temperature and salinity. However, the chlorophyll $a$ - or fucoxanthin-specific DMSP contents were not affected by temperature, salinity or DIN. Simultaneous peaks of DMSP and chlorophyll $a$ and fucoxanthin were observed in spring and in summer, and at 1 station also in winter. These peaks coincided with increases in epipelic diatoms. The DMSP content correlated with chlorophyll $a$ and fucoxanthin and this relationship improved by excluding samples with a low ratio of fucoxanthin to chlorophyll a $(\mathrm{chl} \mathrm{a})$ indicative of a low amount of diatoms relative to other microalgae. The sediment molar ratio of DMSP:chl a was $9.2 \pm 5.6$ and $5.1 \pm 3.6$ for the Wester- and Oosterschelde, respectively, values similar to the cellular ratio in cultured diatoms. These results suggest that diatoms were the most important source of DMSP in the sediment. In summer, cyanobacteria and green algae were also present. While cyanobacteria did not contribute to the DMSP content, the data suggest that the amount of DMSP produced by other algae (probably Euglenophytes) produced similar to that produced by diatoms. Hence, microphytobenthos biomass and community composition were the main factors determining the DMSP content in the intertidal sediments of the Schelde estuary.
\end{abstract}

KEY WORDS: Dimethylsulfoniopropionate - DMSP · Diatoms · Microphytobenthos · Intertidal sediments $\cdot$ Pigments

Resale or republication not permitted without written consent of the publisher

\section{INTRODUCTION}

Dimethylsulfoniopropionate (DMSP) is an organic sulfur compound present in many marine micro- and macroalgae (Keller et al. 1989, Blunden et al. 1992, Yoch 2002). DMSP is the major biochemical precursor of the volatile sulfur species, dimethylsulfide (DMS), which is one of the major biogenic sources of sulfur of the atmosphere (Bates et al. 1992). Charlson et al. (1987) hypothesized that emission of DMS to the atmosphere represents a climate-regulating mechanism. Therefore it is important to identify the sources of DMS and the factors that regulate its emission. The production of DMSP is one of the major processes that determine the potential amount of DMS that can be emitted to the atmosphere, and therefore the distribution of DMSP in marine habitats is of interest. 
In marine pelagic systems, a correlation has been found between chlorophyll a and DMSP (Gröne 1995, Townsend \& Keller 1996), which is in agreement with the algal origin of this compatible solute. However, the correlation between algal biomass and DMSP is sometimes obscured by different levels of production (e.g. intracellular concentration) by different groups or species of algae, or environmental factors influencing the specific DMSP content of algae, such as salinity or nitrogen availability (Turner et al. 1988, Iverson et al. 1989, Townsend \& Keller 1996). DMSP has been suggested to serve as cryo- or osmoprotectant, because its content in marine micro- and macroalgae increases with decreasing temperature or increasing salinity (Sheets \& Rhodes 1996, Yoch 2002, van Bergeijk et al. 2003, Kasamatsu et al. 2004). Furthermore, it has been hypothesized that nitrogen limitation might stimulate DMSP production, because it could replace nitrogencontaining osmolytes, such as glycine betaine or proline (Turner et al. 1988). Evidence for this mechanism has subsequently been provided by some studies (Gröne \& Kirst 1992, Keller et al. 1999), although Keller et al. (2004) concluded that the responses to N supply were more likely attributable to species composition. Sunda et al. (2002) proposed an antioxidant function for DMSP and DMS in marine algae that could protect them from oxidative stress.

Although the surface area of coastal intertidal sediments is small compared to that of the oceans, they are characterized by the occurrence of dense communities of microalgae and often high amounts of DMSP. Therefore, they represent environments with potential high emissions of DMS. It has been shown that in intertidal sediments the vertical distribution of chlorophyll $a$ and DMSP in the sediment is similar (Visscher et al. 1994, van Bergeijk \& Stal 1996, Jonkers et al. 1998), but the correlation between algal pigments and DMSP has not been studied in detail in benthic ecosystems. Microphytobenthos growing in the top layer of intertidal sediment generally consists of diatoms, cyanobacteria, euglenophytes and, occasionally, chlorophytes. DMSP production has been demonstrated in several benthic diatoms (Jonkers et al. 1998), and they are most likely responsible for the bulk of DMSP production in intertidal sediments. Reports on the production of DMSP by marine cyanobacteria are contradictory (Visscher \& van Gemerden 1991, Jonkers et al. 1998). Sunda et al. (2005) showed that pelagic cyanobacteria did not contribute to particulate DMSP. However, it is unclear whether cyanobacteria contribute to the production of DMSP in marine sediments.

In this study, the seasonal variation of DMSP in intertidal sediments was investigated in relation to the microphytobenthic biomass. We studied whether the presence of different groups of oxygenic phototrophic microorganisms affected the DMSP content in 2 estuaries with different sediment characteristics, salinity and nutrient regimes. Furthermore, we evaluated the effects of temperature, salinity, and pore-water nitrogen concentrations on the DMSP and pigment content of the sediments.

\section{MATERIALS AND METHODS}

Study area. Fig. 1 shows the Schelde estuary (SW Netherlands). The Westerschelde is a macrotidal estuary with a fairly stable and gradual salinity gradient, comprising meso-, poly- and euhaline zones (salinities from $\sim 5$ to 33). Because the River Schelde is a 'rain river' that depends on precipitation, freshwater discharge from the River Schelde is subject to seasonal fluctuation. The River Schelde runs through an urbanized and industrialized area of Belgium, and is polluted by discharges of untreated wastes and toxic substances. Therefore, the estuary receives a high load of nutrients and organic material. The Oosterschelde is a mesotidal, euhaline estuary. Freshwater discharge in the Oosterschelde is low. Salinity is around 30 and remains fairly constant from the inner estuary to the

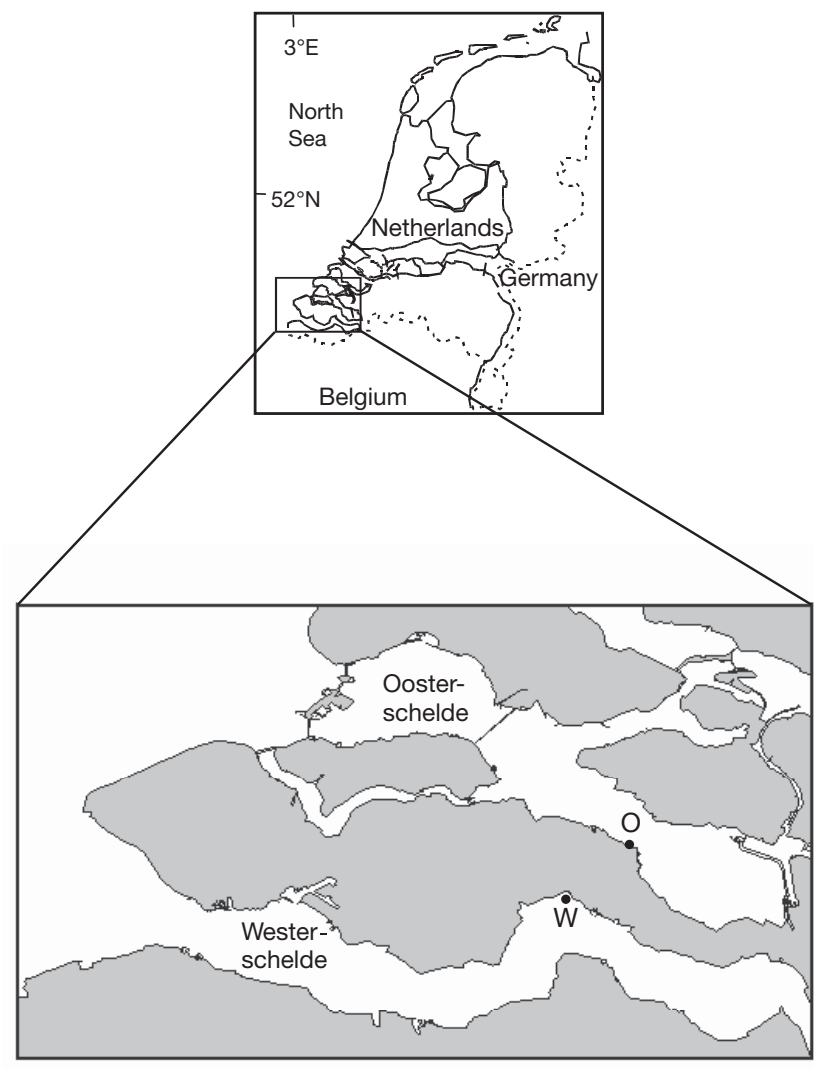

Fig. 1. Study area and location of sampling Stns W (Westerschelde) and $\mathrm{O}$ (Oosterschelde) in the Schelde estuary, SW Netherlands 
mouth. Nutrient concentrations in the Oosterschelde are much lower than in the Westerschelde.

Sampling. Samples were taken monthly from May 1997 until June 1998 from intertidal sediments during low tide at 1 station at the Westerschelde (W) and 1 station at the Oosterschelde (O) (Fig. 1). The sediments were composed of sandy mud and were inundated at every high tide. Sampling was done when low tide occurred during the middle of the day. We took 10 random samples from a permanent quadrat of $4 \mathrm{~m}^{2}$, using stainless-steel cores $(\varnothing 24 \mathrm{~mm})$. For the determination of total DMS(P) and algal pigments, the top $2.5 \mathrm{~mm}$ of the sediment was sliced off the cores using a $2.5 \mathrm{~mm}$-high Perspex ring $(\varnothing 24 \mathrm{~mm})$. The top $2.5 \mathrm{~mm}$ was sampled because this contained virtually all microalgal biomass; thinner slices of sediment led to large variations in biomass due to vertical migration of the benthic diatoms. Preliminary measurements showed that the concentrations of dissolved DMS and DMSP in sediment pore water were below or just around the detection limit (see next subsection), and were negligible compared to the sediment-bound DMSP content (van Bergeijk et al. 2002). Therefore, we measured the total amounts of DMS and DMSP in the sediment. At each sampling point, sedimentsurface temperature was measured. Salinity was measured in the overlying seawater sampled at or very close to the sampling site, after filtering it through a GF/F glass-fiber filter (Whatman). Dissolved inorganic nitrogen (DIN) was measured in pore water collected using Rhizon soil moisture samplers (SMS) (Eijkelkamp Agrisearch Equipment, length $50 \mathrm{~mm}$, diameter $2 \mathrm{~mm})$. The samplers were inserted just below the sediment surface and 3 samples were pooled and stored at $-20^{\circ} \mathrm{C}$ until analysis. The volume of 3 pooled pore-water samples ranged between 3 and $10 \mathrm{ml}$.

All sediment samples were processed in the field, immediately after sampling. The $2.5 \mathrm{~mm}$ slices were cut in half with a small spatula. One half was put in a glass culture tube, covered with Parafilm, and stored on ice in the dark. The tubes were immediately transferred to a freezer $\left(-80^{\circ} \mathrm{C}\right)$ upon return to the laboratory (within $\sim 1 \mathrm{~h}$ ) and stored until the samples were analyzed for pigments. The other half-slice was put in a $6 \mathrm{ml}$ glass vial (Chrompack), after which $2.4 \mathrm{ml}$ filtered seawater and $1 \mathrm{ml} 8 \mathrm{M} \mathrm{NaOH}$ were added. After the addition of $\mathrm{NaOH}$, the vials were immediately closed with gas-tight, Teflon-coated, butyl rubber septa and aluminum crimp-seal caps. The vials were stored at room temperature in the dark and the samples were analyzed for total DMS(P) within $1 \mathrm{wk}$ of sampling (see next subsection).

Surface scrapings of the sediment, fixed with Lugol's fixative, were oxidized with hydrogen peroxide $(30 \%$ $\mathrm{H}_{2} \mathrm{O}_{2}$ ). The oxidized samples, consisting of the silica valves of the diatom frustules, were mounted in Naphrax (a resin of high refractive index) onto glass slides (Battarbee 1986) and subsequently qualitatively analyzed by microscopy. Microscopic observations were made for each sampling time-point.

Analyses. Pigments were extracted from freezedried sediment samples with $96 \%$ methanol containing $4 \%$ ammonium acetate (Zapata \& Garrido 1991). Prior to extraction, the freeze-dried sediment was ground with a bullet grinder for $1 \mathrm{~min}$ at maximum amplitude (ISO 9001 Retch). Half a sediment slice $\left(0.565 \mathrm{~cm}^{3}\right)$ was extracted with $2.5 \mathrm{ml}$ solvent. The samples were vortexed and subsequently ultrasonicated for $10 \mathrm{~min}$ in an ice-cold water bath and then centrifuged for $10 \mathrm{~min}$ at $2800 \times g$ at room temperature.

The pigments were determined by high-performance liquid chromatography (HPLC) according to the method described by Barranguet et al. (1997). The HPLC system was equipped with a photodiode-array detector (Waters 996) coupled to a Waters 717 autosampler, and was calibrated using isolated pigment standards (Barranguet et al. 1997).

DMSP was measured indirectly as DMS, after hydrolysis of DMSP to DMS and acrylate with cold alkali (Challenger et al. 1957). A final concentration of $2 \mathrm{M}$ $\mathrm{NaOH}$ was used to hydrolyze the samples, which were incubated for at least $24 \mathrm{~h}$ prior to analysis. DMS was measured by headspace analysis with a gas chromatograph (CP 9000, Chrompack), equipped with a widebore column (Poraplot U, inner diameter $0.53 \mathrm{~mm}$; $25 \mathrm{~m}$; Chrompack) and a flame-ionization detector (FID). The temperatures of the detector, injector and oven were 200,175 and $150^{\circ} \mathrm{C}$, respectively. The flows of air, $\mathrm{H}_{2}$ and the carrier gas, $\mathrm{N}_{2}$, were 300,30 and $8 \mathrm{ml}$ $\mathrm{min}^{-1}$, respectively. The retention time of DMS was $2.5 \mathrm{~min}$ and the detection limit was less than $1 \mathrm{pmol}$ when the $250 \mu \mathrm{l}$ gas sample was injected. The detection limit of the total amount of DMS(P) was $0.5 \mathrm{nmol}$ $\mathrm{cm}^{-3}$ sediment.

Salinity was measured using a hand refractometer (Atago). DIN was determined with a Skalar 5100 autoanalyzer using standard colorimetric methods.

\section{RESULTS}

Seasonal variation in the abiotic (Fig. 2) and biotic (Fig. 3) factors was observed at Stns W and O. In summer 1997, sediment temperature reached up to $\sim 25$ and $\sim 27^{\circ} \mathrm{C}$ at Stns $\mathrm{O}$ and $\mathrm{W}$, respectively, while in the winter the temperatures were $\sim 1$ and $\sim 7^{\circ} \mathrm{C}$. At Stn W salinity varied from 27 to 19 without any specific pattern while at Stn $\mathrm{O}$, it varied from 38 (in summer) to 23 (in winter) (Fig. 2A,B). Changes in salinity did not follow those in temperature, and variations were presum- 


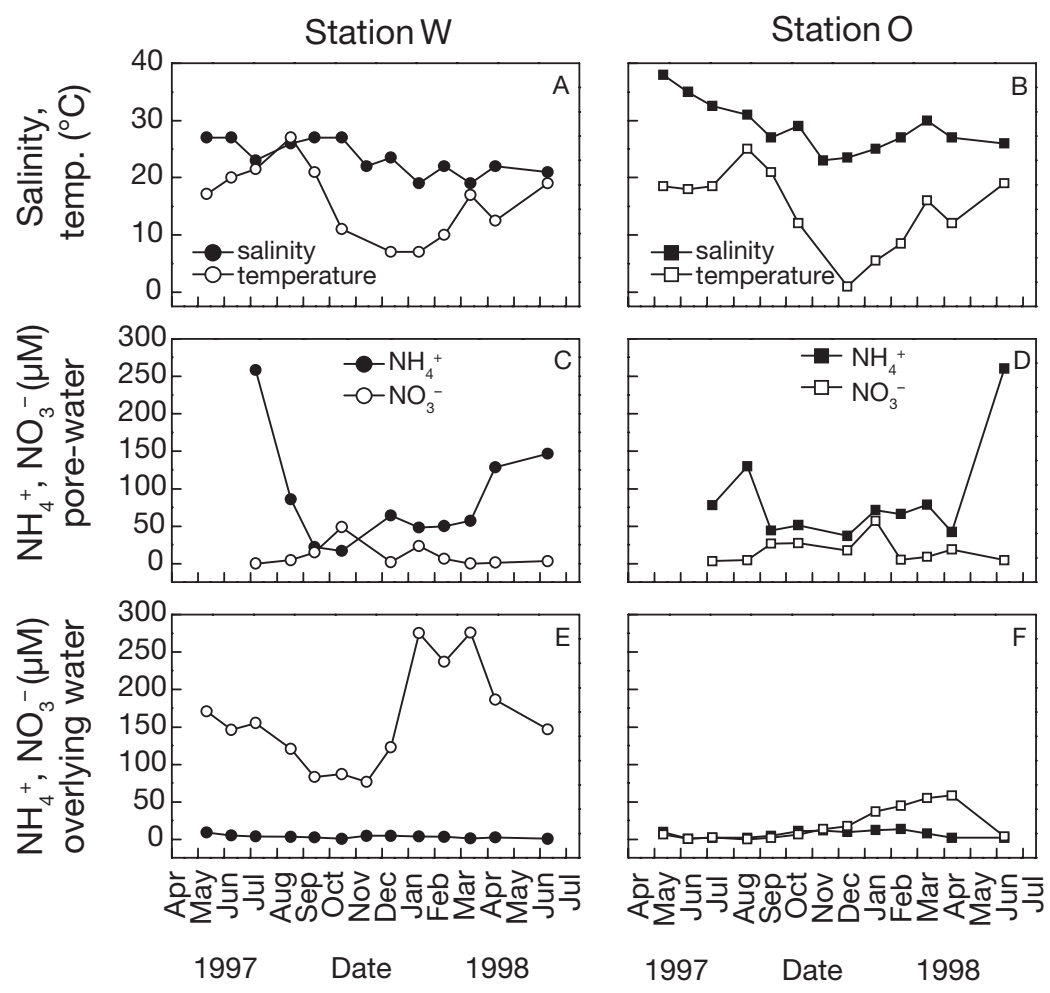

Fig. 2. Seasonal changes in $(A, B)$ temperature and salinity, $(C, D) \mathrm{NH}_{4}{ }^{+}$and $\mathrm{NO}_{3}{ }^{-}$in pore water and $(\mathrm{E}, \mathrm{F}) \mathrm{NH}_{4}{ }^{+}$and $\mathrm{NO}_{3}{ }^{-}$in overlying water at sampling stations in Westerschelde (W) and Oosterschelde (O)
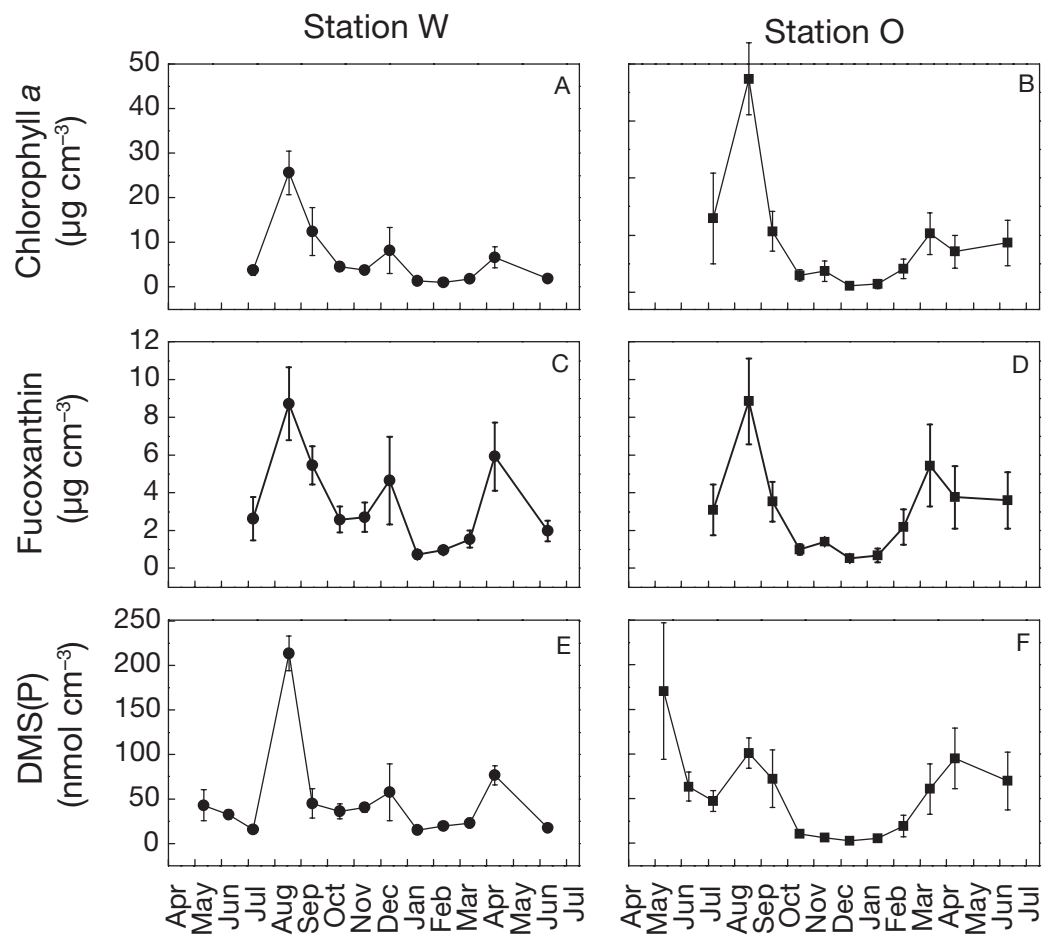

1997 Date 1998
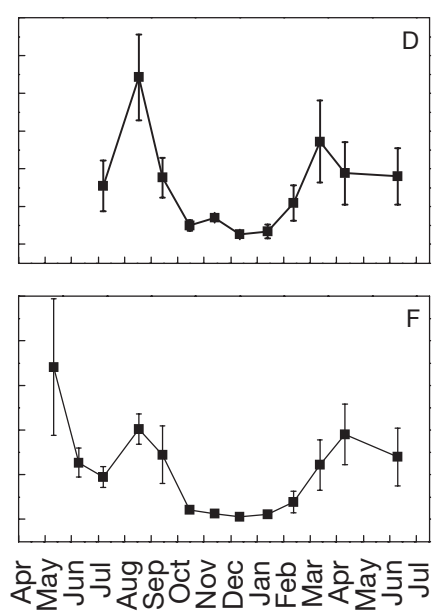

$1997 \quad$ Date 1998

Fig. 3. Seasonal changes in sediment content of $(A, B)$ chlorophyll $a,(C, D)$ fucoxanthin and $(\mathrm{E}, \mathrm{F}) \mathrm{DMS}(\mathrm{P})$ in the upper $2.5 \mathrm{~mm}$ of sediment at Stns $\mathrm{W}$ and $\mathrm{O}$ ably related to differences in freshwater discharge and tides. Pore-water $\mathrm{NO}_{3}{ }^{-}$ concentrations varied throughout the year from 0 to $48 \mu \mathrm{M}$ at Stn $\mathrm{W}$ and 3 to $57 \mu \mathrm{M}$ at Stn $\mathrm{O}$, and were generally lower than $\mathrm{NH}_{4}{ }^{+}$, with 17 to $258 \mu \mathrm{M}$ at W and 37 to $260 \mu \mathrm{M}$ at $\mathrm{O}$ (Fig. $2 \mathrm{C}, \mathrm{D}$ ). $\mathrm{NO}_{3}{ }^{-}$ concentrations were higher in autumn and winter, while $\mathrm{NH}_{4}^{+}$concentrations were much higher in summer than during the rest of the year. Pore-water DIN (Fig. 2C,D) was remarkably different from that in the overlying water (Fig. 2E,F). At both stations, $\mathrm{NO}_{3}^{-}$was higher than $\mathrm{NH}_{4}{ }^{+}$. At $\mathrm{Stn} \mathrm{W}, \mathrm{NH}_{4}{ }^{+}$concentrations were low throughout the year $(0.2$ to $8.6 \mu \mathrm{M})$, while $\mathrm{NO}_{3}{ }^{-}$concentrations were very high, varying from 77 to $276 \mu \mathrm{M}$ with highest values in winter. At $\mathrm{Stn} \mathrm{O}$, concentrations of $\mathrm{NH}_{4}{ }^{+}$were in the same range as in the Westerschelde (0.1 to $13.5 \mu \mathrm{M})$, with the highest occurring in winter. This was also the case with $\mathrm{NO}_{3}{ }^{-}$, but the concentrations (0 to $58.2 \mu \mathrm{M})$ were much lower than in the Westerschelde.

At both stations, diatoms were the dominant oxygenic phototrophic organisms. Stn W was muddy sediment, with a water content of 55 to $75 \%$ and a specific gravity of 1.05 to $1.35 \mathrm{~g} \mathrm{~cm}^{-3}$ wet sediment, while Stn $\mathrm{O}$ was composed of sandy sediment, with a water content of 19.5 to $30 \%$ and a specific gravity of 1.8 to $2.0 \mathrm{~g} \mathrm{~cm}^{-3}$ wet sediment. These differences in sediment characteristics were reflected in the diatom populations present at the stations. At Stn W, occasionally high numbers of epipelic diatoms were observed as well as typical tychoplanktonic species that live in both the benthic and the pelagic. At Stn O, small epipsammic diatoms were present, with occasionally high numbers of large epipelic diatoms. Both stations were characterized by the occurrence of many different species.

Diatoms contain the pigments chlorophyll a and fucoxanthin, which showed a concomitant seasonal variation (Fig. 3A-D). This variation corresponded with the variation in total DMS(P) content (Fig. 3E,F). In August 1997, the chlorophyll a content of the stations was 26 and $37 \mu \mathrm{g} \mathrm{cm}^{-3}$ for Stns W and O, 
respectively, and the $\mathrm{DMS}(\mathrm{P})$ content at these stations was 214 and $101 \mathrm{nmol} \mathrm{cm} \mathrm{cm}^{-3}$, respectively.

In May 1997, the microphytobenthos at Stn W was dominated by Navicula gregaria and $N$. arenaria var. rostellata and at Stn O by $N$. arenaria var. rostellata and $N$. bipustulata. In August 1997, Stn W was dominated by $N$. phyllepta, but also contained several other species (e.g. large Nitzschia spp. and Tryblionella apiculata), and Stn O by Amphora spp. and Nitzschia spp. These species all belong to the group of epipelic diatoms. In August, both stations also contained conspicuous amounts of algae other than diatoms. At Stn W green microalgae (probably euglenophytes) were present, while at Stn O many unicellular and filamentous cyanobacteria were observed. In December 1997, the microphytobenthos at Stn W was dominated by $N$. arenaria var. rostellata. In April 1998, Stn W was dominated by $N$. arenaria var rostellata and Stn O by Amphora spp. and Nitzschia spp.

To investigate whether the observed variation in $\mathrm{DMS}(\mathrm{P})$ and pigments could be explained by the effect of the abiotic factors tested, multiple-regression analyses were performed (Tables 1 \& 2). DMS(P), chlorophyll a and fucoxanthin were all strongly dependent on salinity at Stn W ( $a=0.091,0.140$ and 0.107 , respectively), and on temperature at Stn $O(a=0.060,0.059$ and 0.041 , respectively) (Table 1). A slightly negative relationship was found for DMS(P), chlorophyll a and fucoxanthin with DIN (values varying from -0.0018 to -0.0136 ) (Table 1). Temperature and salinity barely affected the pigmentspecific DMS(P) content. Chlorophyll a-specific $\mathrm{DMS}(\mathrm{P})\left(\mathrm{DMS}(\mathrm{P})_{\mathrm{chl}}\right.$ ) was weakly negatively related to salinity $(a=-0.0503)$, while fucoxanthinspecific DMS(P) (DMS(P) $)_{\text {fuco }}$ ) was weakly negative related to DIN $(a=-0.0174)$ and weakly related to temperature $(a=0.0164)$ (Table 1$)$. Fig. 4 depicts the relation of $\mathrm{DMS}(\mathrm{P})$ with temperature, salinity and DIN. When all measurements of DMS(P) were taken into account a positive relation was obtained with temperature (Fig. 4A) and salinity (Fig. 4B), although the latter was weaker. No relation was found with DIN (Fig. 4C).

Our results demonstrate that DMS(P) content correlated well with microalgal biomass, represented by chlorophyll $a$ and fucoxanthin (Fig. 5). The correlation was better when samples with a low $(\leq 0.3)$ fucoxanthin to chlorophyll a ratio were excluded; 2 groups of samples were easily distinguished from the rest. The samples from August 1997 at Stn W contained green
Table 1. Stepwise, linear, multiple-regression analysis $(y=a x+b)$ of effects of temperature, salinity, $\mathrm{NO}_{3}{ }^{-}$and $\mathrm{NH}_{4}{ }^{+}$on the dependent variables DMS(P) $)_{\text {sediment }}\left(\mathrm{nmol} \mathrm{cm}^{-3}\right.$ sediment), chl a ( $\mu \mathrm{g} \mathrm{cm}^{-3}$ sediment), fucoxanthin $\left(\mu \mathrm{g} \mathrm{cm}^{-3} \text { sediment), DMS(P) }\right)_{\mathrm{chl}}\left(\mathrm{mmol} \mathrm{g}^{-1} \mathrm{chl}\right.$ a) and DMS(P) fuco (mmol g ${ }^{-1}$ fucoxanthin). Dependent variables were ${ }^{10} \log$-transformed to increase homogeneity of variance. Parameter estimates are derived from multiple regressions (intercepts and slopes) and Student's $t$-test for $H_{0}$ that each regression parameter differs from 0 . -: no data

\begin{tabular}{|c|c|c|c|c|}
\hline $\begin{array}{l}\text { Dependent } \\
\text { variable }\end{array}$ & Factor & $\begin{array}{l}\text { Parameter } \\
\text { estimates }\end{array}$ & $t$ & $\mathrm{p}$ \\
\hline \multicolumn{5}{|l|}{ Westerschelde } \\
\hline \multirow{4}{*}{$\mathrm{DMS}(\mathrm{P})_{\text {sediment }}$} & Intercept & -0.259 & -1.08 & 0.281 \\
\hline & Salinity & 0.0906 & 8.69 & $<0.001$ \\
\hline & $\mathrm{NO}_{3}^{-}$ & -0.0136 & -5.84 & $<0.001$ \\
\hline & $\mathrm{NH}_{4}^{+}$ & -0.0018 & -3.84 & $<0.001$ \\
\hline \multirow[t]{3}{*}{ Chlorophyll a } & Intercept & -2.511 & -10.13 & $<0.001$ \\
\hline & Salinity & 0.140 & 12.68 & $<0.001$ \\
\hline & $\mathrm{NO}_{3}^{-}$ & -0.0120 & -5.589 & $<0.001$ \\
\hline \multirow[t]{3}{*}{ Fucoxanthin } & Intercept & -1.916 & -9.72 & $<0.001$ \\
\hline & Salinity & 0.107 & 12.15 & $<0.001$ \\
\hline & $\mathrm{NO}_{3}^{-}$ & -0.0126 & -7.41 & $<0.001$ \\
\hline \multirow{3}{*}{$\mathrm{DMS}(\mathrm{P})_{\mathrm{chl} \mathrm{a}}$} & Intercept & 2.206 & 12.49 & $<0.001$ \\
\hline & Salinity & -0.0503 & -6.85 & $<0.001$ \\
\hline & $\mathrm{NH}_{4}^{+}$ & -0.0013 & -4.47 & $<0.001$ \\
\hline \multirow[t]{3}{*}{$\mathrm{DMS}(\mathrm{P})_{\text {fuco }}$} & Intercept & 1.654 & 9.97 & $<0.001$ \\
\hline & $\mathrm{NH}_{4}^{+}$ & -0.0016 & -5.62 & $<0.001$ \\
\hline & Salinity & -0.0174 & -2.53 & 0.013 \\
\hline \multicolumn{5}{|l|}{ Oosterschelde } \\
\hline \multirow[t]{3}{*}{$\mathrm{DMS}(\mathrm{P})_{\text {sediment }}$} & Intercept & 0.684 & 6.88 & $<0.001$ \\
\hline & Temperature & 0.0601 & 12.07 & $<0.001$ \\
\hline & $\mathrm{NO}_{3}^{-}$ & -0.0045 & -2.08 & 0.041 \\
\hline \multirow[t]{4}{*}{ Chlorophyll a } & Intercept & 0.119 & 1.59 & 0.115 \\
\hline & Temperature & 0.0588 & 15.84 & $<0.001$ \\
\hline & $\mathrm{NO}_{3}^{-}$ & -0.0065 & -4.06 & $<0.001$ \\
\hline & $\mathrm{NH}_{4}^{+}$ & -0.0010 & -2.60 & 0.011 \\
\hline \multirow[t]{3}{*}{ Fucoxanthin } & Intercept & -0.148 & -2.11 & 0.038 \\
\hline & Temperature & 0.0414 & 11.80 & $<0.001$ \\
\hline & $\mathrm{NO}_{3}^{-}$ & -0.0056 & -3.63 & $<0.001$ \\
\hline $\mathrm{DMS}(\mathrm{P})_{\mathrm{chl} a}$ & - & - & - & - \\
\hline \multirow[t]{2}{*}{$\operatorname{DMS}(\mathrm{P})_{\text {fuco }}$} & Intercept & 0.877 & 17.756 & $<0.001$ \\
\hline & Temperature & 0.0164 & 5.226 & $<0.001$ \\
\hline
\end{tabular}

Table 2. Results of ANOVA testing overall significance of multiple regressions in Table 1

\begin{tabular}{|lcc|}
\hline Dependent variable & $\mathrm{p}$ & $\mathrm{R}^{2}$ \\
\hline Westerschelde & & \\
DMS(P) sediment $_{\text {Chlorophyll } a}$ & $<0.001$ & 0.49 \\
Fucoxanthin & $<0.001$ & 0.63 \\
DMS(P) & $<0.001$ & 0.62 \\
DMS $a$ & $<0.001$ & 0.37 \\
& $<0.001$ & 0.26 \\
Oosterschelde & & \\
DMS(P) & & \\
Chlorophyment & $<0.001$ & 0.72 \\
Fucoxanthin & $<0.001$ & 0.83 \\
DMS(P) & $<0.001$ & - \\
DMS $a$ & - & 0.74 \\
fhico & $<0.001$ & \\
\hline
\end{tabular}



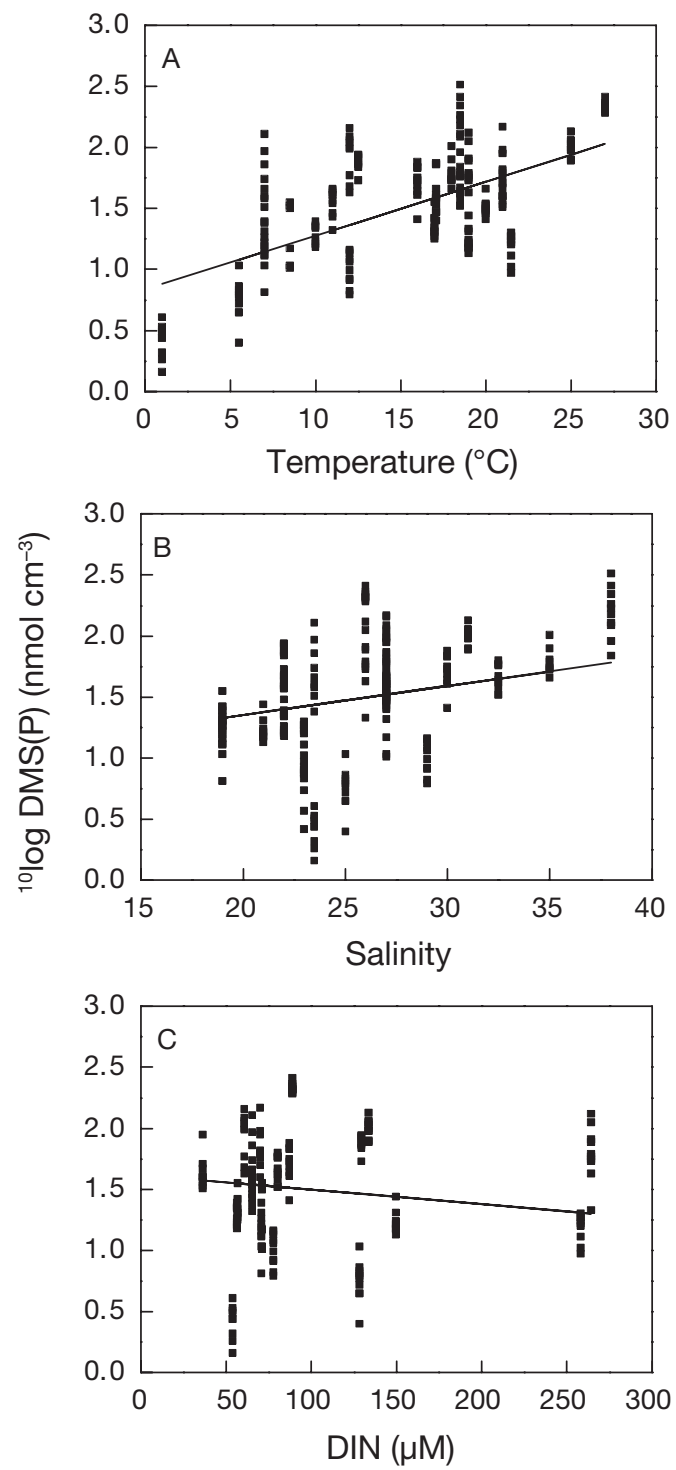

Fig. 4. Total sediment content of DMS(P) in all samples taken during $1 \mathrm{yr}$ at Stns $\mathrm{O}$ and $\mathrm{W}$ combined, plotted against (A) temperature, (B) salinity, and (C) dissolved inorganic nitrogen $\left(\right.$ DIN $\left.=\mathrm{NO}_{3}{ }^{-}+\mathrm{NH}_{4}{ }^{+}\right)$. Lines $=$data fitted with least-squares multiple-regression equation $(\mathrm{p}<0.05)$ : $y=0.0441$ temperature + 0.0238salinity - 0.0012DIN + 0.338: $\mathrm{r}^{2}=0.49 ; \mathrm{N}=192$; with (A) salinity 26 and DIN $101 \mu \mathrm{M}$, (B) with temperature of $15^{\circ} \mathrm{C}$, and DIN $101 \mu \mathrm{M}$ and $(\mathrm{C})$ with temperature of $15^{\circ} \mathrm{C}$ and salinity 26

microalgae, and those from July and August 1997 at Stn O contained cyanobacteria. Green algae and cyanobacteria contain chlorophyll $a$, but lack fucoxanthin. This was reflected by the low fucoxanthin to chlorophyll a ratio $(\leq 0.3)$ in these samples. Sediments dominated by diatoms typically possess a ratio of fucoxanthin to chlorophyll $a$ of 0.6 to 0.8 (Lucas \& Holligan 1999). Samples taken at Stn W in September 1997 also possessed a low fucoxanthin to chlorophyll a ratio but we lack microscopic observations on the microalgal composition of this sample. Omitting the data from July and August at Stn O strongly improved the correlation between chlorophyll $a$ and DMS(P) and decreased the slope of the regression line (Fig. 5A). Omission of these data barely changed the correlation between fucoxanthin and DMS(P) or the slope of the regression line (Fig. 5B). When the data from September at Stn W were omitted, the correlation between chlorophyll $a$ and DMS(P) increased, but the slope of the regression line remained almost the same (Fig. 5C). The slope of the regression line clearly decreased as well as the correlation between chlorophyll $a$ and DMS(P) when the data from August were omitted (Fig. 5C). In contrast, the correlation between fucoxanthin and $\mathrm{DMS}(\mathrm{P})$ increased, while the slope of the regression line decreased, when the data from August were omitted (Fig. 5D). Omission of the data from September scarcely affected the correlation between fucoxanthin and DMS(P) or the slope of the regression line (Fig. 5D). These results suggest that the samples with a low fucoxanthin to chlorophyll a ratio can be divided into different groups. The samples from July and August 1997 at Stn O and from September 1997 at Stn W represents a group with a low DMS(P) to chlorophyll a ratio. The samples from August 1997 at Stn W represent another group with an average DMS(P) to chlorophyll a ratio $(8.6 \pm 1.5)$ comparable to the rest of the samples.

The average total $\mathrm{DMS}(\mathrm{P})$ concentrations were $57.1 \pm 54.8$ and $49.0 \pm 52.7 \mathrm{nmol} \mathrm{cm}{ }^{-3}$ sediment for Stns $\mathrm{O}$ and $\mathrm{W}$, respectively. The average chlorophyll aand fucoxanthin-specific DMS(P) concentrations were $5.8 \pm 4.1$ and $10.3 \pm 6.3 \mathrm{mmol}(\mathrm{g} \text { chlorophyll } \mathrm{a})^{-1}$ and $14.1 \pm 8.8$ and $14.9 \pm 6.4 \mathrm{mmol}(\mathrm{g} \text { fucoxanthin })^{-1}$ for Stns $\mathrm{O}$ and $\mathrm{W}$, respectively.

\section{DISCUSSION}

Using pigment biomarkers, Barranguet et al. (1997) studied microphytobenthic biomass and community structure during $1 \mathrm{yr}$ at a tidal flat in the Westerschelde. They observed that during spring and autumn blooms the population was dominated by diatoms, while in summer diatoms coexisted with cyanobacteria and Euglenophyceae. We observed a similar succession from diatoms in spring to diatoms and cyanobacteria in summer at $\mathrm{Stn} \mathrm{O}$ and diatoms and green algae in summer at Stn $\mathrm{W}$ in summer. The seasonal variation in microphytobenthic community composition was also in accordance with results of the study of Watermann et al. (1999), who found that cyanobacteria are favored by higher temperature while diatoms start to develop when the temperature is still low. Nevertheless, 

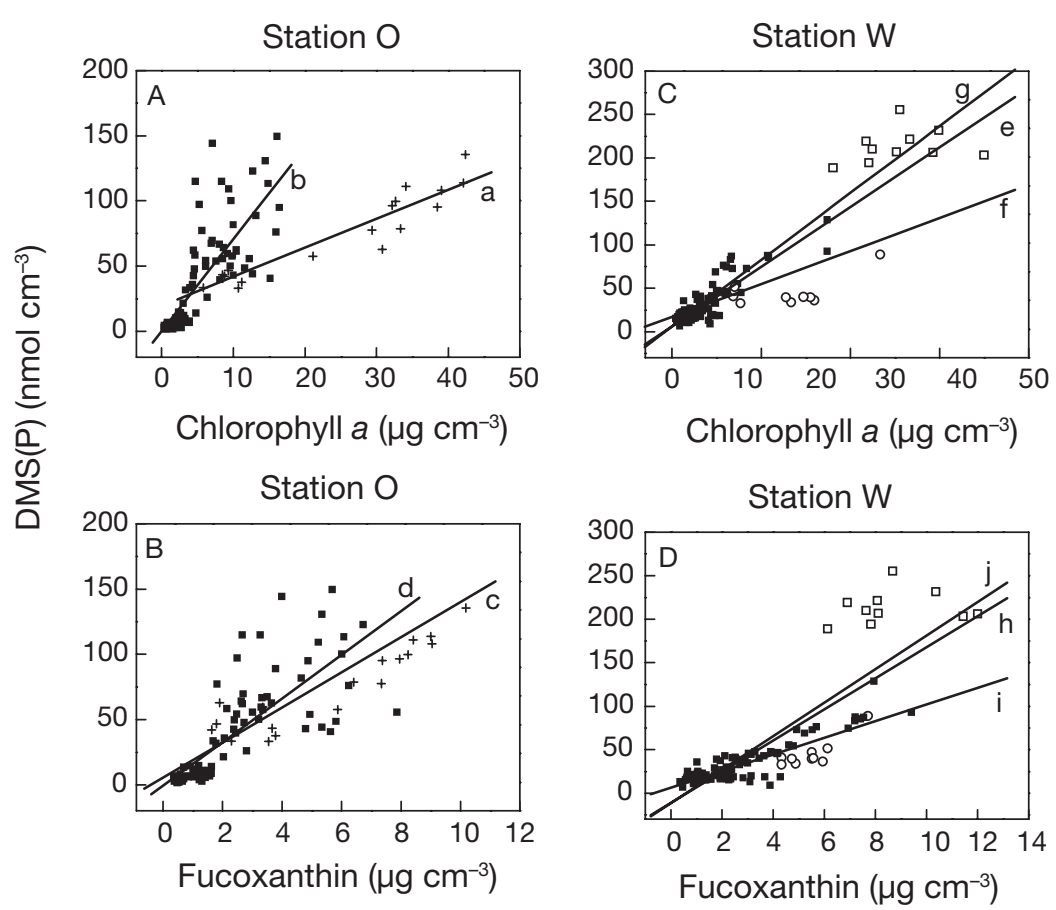

Fig. 5. Total sediment content of $\mathrm{DMS}(\mathrm{P})$ plotted against sediment content of chlorophyll $a$ and fucoxanthin at (A,B) Stn O and (C,D) Stn W. (+) Samples taken at Stn O, July and August 1997 (containing cyanobacteria); () Samples taken at Stn W, August 1997 (containing green algae); (o) Samples taken at Stn W, September 1997 (probably containing green algae); (匹) Other samples (containing mainly diatoms). Data fitted with least-squares regression equations $(\mathrm{p}<0.05)$ : a: $y=2.80 x+20.4, \mathrm{r}^{2}=0.47, \mathrm{~N}=101$ (Stn O, all data)

b: $y=7.05 x+0.12, \mathrm{r}^{2}=0.62, \mathrm{~N}=83$ (Stn $\mathrm{O}$, all data except Jul \& Aug)

c: $y=13.84 x+5.39, \mathrm{r}^{2}=0.65, \mathrm{~N}=101$ (Stn $\mathrm{O}$, all data)

d: $y=16.73 x-0.70, \mathrm{r}^{2}=0.62, \mathrm{~N}=83$ (Stn O, all data except Jul \& Aug)

e: $y=6.87 x+6.23, \mathrm{r}^{2}=0.82, \mathrm{~N}=109$ (Stn $\mathrm{W}$, all data)

f: $y=3.80 x+17.0, r^{2}=0.50, N=99$ (Stn W, all data except Aug)

g: $y=7.69 x+6.12, r^{2}=0.92, N=99($ Stn $\mathrm{W}$, all data except Sep)

h: $y=17.19 x-11.28, \mathrm{r}^{2}=0.69, \mathrm{~N}=109$ (Stn W, all data)

i: $y=9.57 x+6.20, \mathrm{r}^{2}=0.74, \mathrm{~N}=99$ (Stn W, all data except Aug)

$\mathrm{j}: y=19.28 \mathrm{x}-11.55, \mathrm{r}^{2}=0.75, \mathrm{~N}=99$ (Stn W, all data except Sep)

growth of diatoms is stimulated by increasing temperature. Chlorophyll $a$ and fucoxanthin were positively related with temperature and salinity, confirming the findings of Santos et al. (1997). The total DMS(P) content was similarly related to temperature and salinity and, not surprisingly, DMS(P) therefore correlated well with chlorophyll a and fucoxanthin. Hence, we conclude that diatoms comprise an important source of DMSP in these intertidal sediments.

In summer, cyanobacteria were present at Stn O. Had they produced DMSP, a higher DMS(P) to fucoxanthin ratio compared to that of sediments containing mainly diatoms would be expected, because cyanobacteria contain chlorophyll a but lack fucoxanthin. Since this was not the case and (in addition) the ratio of $\mathrm{DMS}(\mathrm{P})$ to chlorophyll a decreased, this was taken as evidence that cyanobacteria did not contribute substantially to the production of DMSP. In summer, green algae (probably Euglenophytes) were present at Stn W. These organisms also contain chlorophyll $a$ and lack fucoxanthin. Samples from August with a low fucoxanthin to chlorophyll a ratio improved the correlation between DMS(P) and chlorophyll $a$, while samples from September with a similar low fucoxanthin to chlorophyll a ratio decreased this correlation. Moreover, while the August samples increased the DMS(P) to fucoxanthin ratio, the samples of September scarcely affected this ratio. This could mean that some green algae may have contributed to the production of DMSP at Stn W while others did not.

DMSP production has been shown in axenic cultures of various benthic diatoms isolated from intertidal sediments, including from the Schelde estuary (van Bergeijk \& Stal 1996, Jonkers et al. 1998). The conclusion that cyanobacteria are unlikely to contribute to DMSP production in intertidal sediments is supported by the fact that it has not been demonstrated in cultures. One report that DMSP was present in the mat-forming cyanobacterium Microcoleus chthonoplastes Strain 11 (Visscher \& van Gemerden 1991) could not be reproduced (van Bergeijk \& Stal 1996, Jonkers et al. 1998, Vogt et al. 1998). However, the prasinophycean alga Tetraselmis sp. (a symbiont of the marine flatworm Convoluta roscoffensis that inhabits intertidal sediments) has been shown to contain high amounts of DMSP (van Bergeijk \& Stal 2001). Whether euglenophytes are able to produce DMSP is not known.

Analysis of the correlation of the pigment-specific content of DMSP in intertidal sediments presents an alternative approach for evaluating the contribution of different members of the microphytobenthos. Using chlorophyll $a$ and fucoxanthin as markers for diatoms, the contribution of these organisms to the DMSP production in intertidal sediments was successfully distinguished. When more detailed pigment fingerprints are available, this method will become feasible for other groups of microphytobenthos.

The molar ratio of DMS(P):chlorophyll a varied between $5.1 \pm 3.6$ and $9.2 \pm 5.6$ at the Oosterschelde and Westerschelde stations, respectively. These ratios are considerably lower than that found in phytoplankton, which can be in the order of 30 to 40 (Keller et al. 2004, Sunda et al. 2005). However, it matches nicely the 
ratios of 4.5 to 8.7 reported by Kasamatsu et al. (2004) for isolates of psychrophilic diatoms. It also agrees with the ratio of 8.2 at a salinity of 33 reported for a culture of the benthic diatom Cylindrotheca closterium by van Bergeijk et al. (2003). This can be taken as further evidence for the contribution of diatoms to the DMS(P) production in intertidal sediments.

Contrary to expectations, we did not find correlations between the chlorophyll $a-$ or fucoxanthinspecific DMS(P) content and temperature, salinity or DIN. DMSP is thought to serve as a cryo- or osmoprotectant (Sheets \& Rhodes 1996, Yoch 2002, van Bergeijk et al. 2003, Kasamatsu et al. 2004). This would mean that the biomass-specific DMSP content is expected to be higher with increasing salinity or with decreasing temperature. However, such effects would be obscured by the large seasonal variations in biomass and composition of the microphytobenthos (Keller et al. 2004, Kulkarni et al. 2005). Moreover, the variations in salinity at the sampling locations were too small to cause measurable changes in the community DMSP content, and the dynamics of DMSP content in microphytobenthos are slow (van Bergeijk et al. 2002, 2003).

Similarly, we considered the possibility that the pigment-specific DMSP content differed at the 2 stations. Under nitrogen limitation, DMSP might replace nitrogen-containing osmolytes such as glycine betaine or proline (Gröne \& Kirst 1992, Keller et al. 1999). However, we did not find any difference in chlorophyll aspecific DMS(P) content between the 2 stations. The concentrations of DIN in the pore water at both stations were similar and high. Therefore, we considered nitrogen limitation unlikely, at least not on the longer timescales of this study. This observation agrees also with those of Keller et al. (2004), who concluded that responses to nitrogen supply were attributable to species composition and the physiological state of organisms present. Moreover, the average pigment and DMS(P) contents at both stations were also similar. These results agree with the assumption that in neither the Westerschelde nor Oosterschelde is microphytobenthic production limited by nutrients (de Jong \& de Jonge 1995, Kromkamp et al. 1995, Barranguet et al. 1998).

In summary, benthic diatoms were identified as the most important producers of DMSP in the intertidal sediments of the Schelde estuary. Cyanobacteria probably did not contribute to DMSP production, but other algae (perhaps euglenophytes) might also contribute to the DMSP content of the sediment. The fucoxanthinspecific DMSP content, presumed to originate from diatoms, seemed fairly constant, and did not vary with environmental variables such as temperature, salinity or DIN.
Acknowledgements. We are grateful to Mr. J. Sinke and Dr. J. Middelburg (NIOO-KNAW) for analysis of pigments and DIN, to Dr. K. Sabbe (University of Ghent) for his help with the identification of diatoms, and to Dr. J. Huisman (University of Amsterdam) for his help with statistics and valuable comments on the manuscript. This work was supported by the Netherlands Organization for Scientific Research (NWO), grant 770-50-245. This is NIOO Publication No. 3895.

\section{LITERATURE CITED}

Barranguet C, Herman PMJ, Sinke JJ (1997) Microphytobenthos biomass and community composition studied by pigment biomarkers: importance and fate in the carbon cycle of a tidal flat. J Sea Res 38:59-70

Barranguet C, Kromkamp J, Peene J (1998) Factors controlling primary production and photosynthetic characteristics of intertidal microphytobenthos. Mar Ecol Prog Ser 173:117-126

Bates TS, Lamb BK, Guenther A, Dignon J, Stoiber RE (1992) Sulfur emissions to the atmosphere from natural sources. J Atmos Chem 14:315-317

Battarbee RW (1986) Diatom analysis. In: Berglund BE (ed) Handbook of holocene palaeoecology and palaeohydrology. John Wiley \& Sons, London, p 527-570

Blunden G, Smith BE, Irons MW, Yang MH, Roch OG, Patel AV (1992) Betaines and tertiary sulphonium compounds from 62 species of marine algae. Biochem Syst Ecol 20: 373-388

Challenger F, Bywood R, Thomas P, Hayward BJ (1957) Studies on biological methylation. XVII. The natural occurrence and chemical reactions of some thetins. Arch Biochem Biophys 69:514-523

Charlson RJ, Lovelock JE, Andreae MO, Warren SG (1987) Oceanic phytoplankton, atmospheric sulphur, cloud albedo and climate. Nature 326:655-661

de Jong DJ, de Jonge VN (1995) Dynamics and distribution of microphytobenthic chlorophyll $a$ in the Western Scheldt estuary (SW Netherlands). Hydrobiologia 311:21-30

Gröne T (1995) Biogenic production and consumption of dimethylsulfide (DMS) and dimethylsulfoniopropionate (DMSP) in the marine epipelagic zone: a review. J Mar Syst 6:191-209

Gröne T, Kirst GO (1992) The effect of nitrogen deficiency, methionine and inhibitors of methionine metabolism on the DMSP contents of Tetraselmis subcordiformis (Stein). Mar Biol 112:497-503

Iverson RL, Nearhoof FL, Andreae MO (1989) Production of dimethylsulfonium propionate and dimethylsulfide by phytoplankton in estuarine and coastal waters. Limnol Oceanogr 34:53-67

Jonkers HM, Koopmans GF, van Gemerden H (1998) Dynamics of dimethyl sulfide in a marine microbial mat. Microb Ecol 36:93-100

Kasamatsu N, Hirano T, Kudoh S, Odate T, Fukuchi M (2004) Dimethylsulfoniopropionate production by psychrophilic diatom isolates. J Phycol 40:874-878

Keller MD, Bellows WK, Guillard RRL (1989) Dimethyl sulfide production in marine phytoplankton. In: Saltzman E, Cooper WJ (eds) Biogenic sulfur in the environment. American Chemical Society, Washington, DC, p 167-182

Keller MD, Kiene RP, Matrai PA, Bellows WK (1999) Production of glycine betaine and dimethylsulfoniopropionate in marine phytoplankton. II. N-limited chemostat cultures. Mar Biol 135:249-257

Keller MD, Matrai PA, Kiene RP, Bellows WK (2004) 
Responses of coastal phytoplankton populations to nitrogen additions: dynamics of cell-associated dimethylsulfoniopropionate (DMSP), glycine betaine, and homarine. Can J Fish Aquat Sci 61:685-699

Kromkamp J, Peene J, van Rijswijk P, Sandee A, Goosen N (1995) Nutrients, light and primary production by phytoplankton and microphytobenthos in the eutrophic, turbid Westerschelde estuary (the Netherlands). Hydrobiologia 311:9-19

Kulkarni NR, White DL, Lewitus AJ, Tymowski RG, Yoch DC (2005) Dimethylsulfoniopropionate in a salt marsh estuary: correlation to tidal cycle and phytoplankton assemblage composition. Mar Ecol Prog Ser 289:13-25

Lucas CH, Holligan PM (1999) Nature and ecological implications of algal pigment diversity on the Molenplaat tidal flat (Westerschelde estuary, SW Netherlands). Mar Ecol Prog Ser 180:51-64

Santos PJP, Castel J, Souza-Santos LP (1997) Spatial distribution and dynamics of microphytobenthos biomass in the Gironde estuary (France). Oceanol Acta 20:549-556

Sheets EB, Rhodes D (1996) Determination of DMSP and other onium compounds in Tetraselmis subcordiformis by plasma desorption mass spectrometry. In: Kiene RP, Visscher PT, Keller MD, Kirst GO (eds) Biological and environmental chemistry of DMSP and related sulfonium compounds. Plenum Press, New York, p 55-63

Sunda W, Kieber DJ, Kiene RP, Huntsman S (2002) An antioxidant function for DMSP and DMS in marine algae. Nature 418:317-320

Sunda WG, Litaker RW, Hardison DR, Tester PA (2005) Dimethylsulfoniopropionate (DMSP) and its relation to algal pigments in diverse waters of the Belize coastal lagoon and barrier reef system. Mar Ecol Prog Ser 287: $11-22$

Townsend DW, Keller MD (1996) Dimethylsulfide (DMS) and dimethylsulfoniopropionate (DMSP) in relation to phytoplankton in the Gulf of Maine. Mar Ecol Prog Ser 137: 229-241

Turner SM, Malin G, Liss PS, Harbour DS, Holligan PM (1988) The seasonal variation of dimethyl sulfide and dimethyl-

Editorial responsibility: Otto Kinne (Editor-in-Chief), Oldendorf/Luhe, Germany sulfoniopropionate concentrations in nearshore waters. Limnol Oceanogr 33:364-375

van Bergeijk SA, Stal LJ (1996) The role of oxygenic phototrophic microorganims in production and conversion of dimethylsulfoniopropionate and dimethylsulfide in microbial mats. In: Kiene RP, Visscher PT, Keller MD, Kirst GO (eds) Biological and environmental chemistry of DMSP and related sulfonium compounds. Plenum Press, New York, p 369-379

van Bergeijk SA, Stal LJ (2001) Dimethylsulfoniopropionate and dimethylsulfide in the marine flatworm Convoluta roscoffensis and its algal symbiont. Mar Biol 138:209-216

van Bergeijk SA, Schönefeldt K, Stal LJ, Huisman J (2002) Production and consumption of dimethylsulfide (DMS) and dimethylsulfoniopropionate (DMSP) in a diatom-dominated intertidal sediment. Mar Ecol Prog Ser 231:37-46

van Bergeijk SA, van der Zee C, Stal LJ (2003) Uptake and excretion of dimethylsulphoniopropionate is driven by salinity changes in the marine benthic diatom Cylindrotheca closterium. Eur J Phycol 38:341-349

Visscher PT, van Gemerden H (1991) Production and consumption of dimethylsulfonio-propionate in marine microbial mats. Appl Environ Microbiol 57:3237-3242

Visscher PT, Kiene RP, Taylor BF (1994) Demethylation and cleavage of dimethylsulfoniopropionate in marine intertidal sediments. FEMS Microbiol Ecol 14:179-190

Vogt C, Rabenstein A, Rethmeier J, Fischer U (1998) Alkalilabile precursors of dimethyl sulfide in marine benthic cyanobacteria. Arch Microbiol 169:263-266

Watermann F, Hillebrand H, Gerdes G, Krumbein WE, Sommer U (1999) Competition between benthic cyanobacteria and diatoms as influenced by different grain sizes and temperatures. Mar Ecol Prog Ser 187:77-87

Yoch DC (2002) Dimethylsulfoniopropionate: its sources, role in the marine food web, and biological degradation to dimethylsulfide. Appl Environ Microbiol 68:5804-5815

Zapata M, Garrido JL (1991) Influence of injection conditions in reversed-phase high-performance liquid chromatography of chlorophylls and carotenoids. Chromatographia 31:589-594

Submitted: July 22, 2005; Accepted: December 22, 2005 Proofs received from author(s): August 11, 2006 